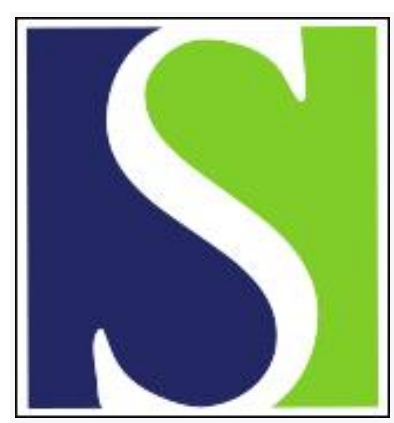

Scand J Work Environ Health 1984;10(1):43-50

https://doi.org/10.5271/sjweh.2364

Issue date: Feb 1984

A prospective follow-up study on psychological effects in workers exposed to low levels of lead.

by Mantere P, Hanninen H, Hernberg S, Luukkonen R

This article in PubMed: www.ncbi.nlm.nih.gov/pubmed/6740276

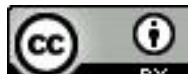




\title{
A prospective follow-up study on psychological effects in workers exposed to low levels of lead
}

\author{
by Pirjo Mantere, MA, Helena Hänninen, LPh, Sven Hernberg, MD, Ritva Luukkonen, MSc ${ }^{1}$
}

\begin{abstract}
MANTERE P, HÄNNINEN H, HERNBERG S, LUUKKONEN R. A prospective follow-up study on psychological effects in workers exposed to low levels of lead. Scand $j$ work environ health 10 (1984) 43-50. A prospective follow-up study on new lead workers who began work at a storage battery factory was carried out between 1975 and 1981. Psychological performances (eg, intelligence, memory, visuomotor functions, vigilance, and personality) were assessed before the commencement of exposure and after one, two, and four years of work. Of an initial number of 89 workers, 24 were available for the one-year, 16 for the two-year, and 11 for the four-year reexamination. The time-weighted average blood lead values ranged between 0.68 and $2.17 \mu \mathrm{mol} / 1$ (14 and $45 \mu \mathrm{g} / 100 \mathrm{ml}$, respectively). A reference group, nonexposed workers in a cable manufacturing plant and an electrical power plant, was similarly followed. Initially the average psychological performances were similar among the lead workers and the referents. For some of the psychological tests learning effect, which was clearly evident among the referents during the follow-up, was almost absent among the lead workers. The lead worker's visual intelligence and visuomotor functions in particular were impaired significantly after the first two years of follow-up. When the lead workers were divided into two groups according to the median timeweighted average of the blood lead values $(1.30 \mu \mathrm{mol} / 1)$, the Block Design and the Santa Ana coordination tests were those which best separated the subgroups. Although the impairment of the lead workers' performance was rather slight and the dispersion in the psychological changes was wide, it was evident that some higher nervous functions were affected by lead levels above about $1.45 \mu \mathrm{mol} / 1$.
\end{abstract}

Key terms: blood lead levels, dose-response relationship, psychological performance, subclinical central nervous system impairment.

Improved health care systems have decreased the number of overt cases of occupational lead poisoning, but the consequences of long-term, moderately increased lead absorption still remain a concern (24). Recently it has been demonstrated that behavioral impairment occurs even at relatively low levels of absorption $(4,6,8,9,12,14,18,19,22)$. At present the threshold for these effects is not known with certainty, but our previous results have indicated that slight effects may occur even below a blood lead (B$\mathrm{Pb})$ level of $1.93 \mu \mathrm{mol} / \mathrm{l}(40 \mu \mathrm{g} / 100 \mathrm{ml})(9,13)$, which is the health-based limit for occupational exposure recommended by the World Health Organization (23). To increase the sensitivity of our previous study design by controlling for interindividual variability, we initiated, in 1975, a prospective follow-up study of newly employed workers not previously occupationally exposed to lead. The follow-up was to focus on both behavioral and neurophysiological effects. We found that especially the sensory conduction

\footnotetext{
1 Department of Psychology and Department of Epidemiology and Biometry, Institute of Occupational Health, Helsinki, Finland.
}

Reprint requests to: Ms $\mathrm{P}$ Mantere, Institute of Occupational Health, Haartmaninkatu 1, SF-00290 Helsinki, Finland. velocities of the median nerve decreased during two years of follow-up (16). In the present paper we purport to show that some psychological functions were also impaired for the same group of workers.

\section{Subjects and methods}

\section{Subjects, referents, and assessment of exposure}

The exposed subjects were recruited from among workers newly employed at a storage battery plant between 1 September 1975 and 1 February 1977. All of the 89 employees hired during that period were enrolled. None had had previous occupational exposure to lead or any other neurotoxic chemical, but five workers were disqualified because of previous illness which could affect the results. After an initial examination, the workers were reexamined after one year, two years, and four years of work.

The turnover rate was very high at the beginning. Only 24 of those initially examined were available for the one-year reexamination. Their age ranged from 18 to 54 years, the mean age being 30.5 (SD 10.1) years. Seven of the workers were women. At the twoyear reexamination only 16 subjects (10 men, 6 women) were still employed and available for the 
study. At the four-year reexamination only 11 subjects (six men, five women) remained. Table 1 shows the age distribution and the $\mathrm{B}-\mathrm{Pb}$ levels during the follow-up period.

The referents were recruited from workers at a cable manufacturing plant and an electrical power plant. All of them worked in departments where exposure to lead did not occur, and they had never been occupationally exposed to any neurotoxic agent. At the outset there were 33 referents $(29$ men and 4 women), and they had been employed at their respective plants for at least two years. Their age ranged from 23 to 43 years, the mean age being 31.0 (SD 5.6) years. Of the referents, 31 came for the two-year reexamination, whereas only 10 were available for the four-year reexamination (six men, four women). The educational background of the referents was the same as that of the lead workers. Their use of medicines, alcohol, and tobacco did not differ from that of the exposed workers.

Both the exposed subjects and the referents were examined with exactly the same methods and during the same calendar periods. The lead workers had their initial examination within one to six weeks after they began work in the storage battery plant. This slight delay, although not optimal, was considered insignificant with regard to the development of toxic effects. However, it explains why the exposed subjects had higher $\mathrm{B}-\mathrm{Pb}$ levels than the referents in the initial examination. Both the initial and the consecutive examinations during the follow-up included the same psychological and neurophysiological measurements.

The $B-P b$ levels of both the exposed subjects and the referents were recorded at the time of the examinations. The $\mathrm{B}-\mathrm{Pb}$ values for the exposed subjects were also regularly recorded during the entire followup period, at intervals of two months.

The $\mathrm{B}-\mathrm{Pb}$ concentration was always measured from duplicate samples by atomic absorbtion spectrophotometry (11). Strict quality control was adopted. The results of this quality control, including those of the most recent interlaboratory checks, have been reported in prior publications $(9,15,16)$ and have been excellent. The concentration of zinc protoporphyrin in the erythrocytes was measured according to Blumberg et al (1).

The $\mathrm{B}-\mathrm{Pb}$ results for different examinations are presented in table 1. The lead workers' levels of both $\mathrm{B}-\mathrm{Pb}$ and zinc protoporphyrin rose mainly during the first year of exposure. The time-weighted averages of the $\mathrm{B}-\mathrm{Pb}$ levels were used to describe the uptake of lead among the exposed workers, as these values discriminated between the subgroups better than the actual $\mathrm{B}-\mathrm{Pb}$ values, the maximum $\mathrm{B}-\mathrm{Pb}$ value, or the level of zinc protoporphyrin. The mean values of the $\mathrm{B}-\mathrm{Pb}$ levels measured at each reexamination were used for the referents.

The exposed workers were divided into two subgroups with the median values of the time-weighted averages of the $\mathrm{B}-\mathrm{Pb}$ values $(1.30 \mu \mathrm{mol} / \mathrm{l})$ as the splitting point. The subgroups thereby obtained at the one-year reexamination were then kept as such, ie, the "low lead" and the "high lead" groups comprised the same workers as the year before.

\section{Psychological methods}

Consecutive psychological examinations took place at one, two and four years after the initial examination. The clinical psychological examination comprised a structured interview (history and changes in the workers's life and health, each worker's assessment of his work load and tasks, etc), a questionnaire on a variety of subjective symptoms, a performance test battery, and a personality inventory. The examination, performed separately for each worker, lasted about $1 \mathrm{~h}$. The psychologist did not know the $\mathrm{B}-\mathrm{Pb}$ values of the subject being tested.

The psychological evaluation included tests for intelligence, memory, visuomotor functions, vigilance, and personality. These tests are generally considered sensitive to disturbances of the central ner-

Table 1. Age, blood lead (B-Pb) levels, and erythrocyte protoporphyrin ( $\mathrm{nnPP}$ ) concentrations of lead workers and referents during a follow-up period of four years.

\begin{tabular}{|c|c|c|c|c|c|c|c|c|c|c|}
\hline \multirow[t]{2}{*}{ Group } & \multirow[t]{2}{*}{$N$} & \multicolumn{2}{|c|}{$\begin{array}{c}\text { Age } \\
\text { (years) }\end{array}$} & \multicolumn{2}{|c|}{$\begin{array}{c}\text { Actual B-Pb } \\
(\mu \mathrm{mol} / \mathrm{l})\end{array}$} & \multirow[b]{2}{*}{ Range } & \multicolumn{2}{|c|}{$\begin{array}{c}\text { Time-weighted } \\
\mathrm{B}-\mathrm{Pb} \\
(\mu \mathrm{mol} / \mathrm{l})\end{array}$} & \multicolumn{2}{|c|}{$\underset{(\mu \mathrm{g} / 100 \mathrm{ml})}{\mathrm{ZnPPa}}$} \\
\hline & & Mean & SD & Mean & SD & & Mean & Median & Mean & SD \\
\hline \multicolumn{11}{|l|}{ Lead workers } \\
\hline $\begin{array}{l}\text { Initial } \\
\text { One-year reexamination } \\
\text { Two-year reexamination } \\
\text { Four-year reexamination }\end{array}$ & $\begin{array}{l}24 \\
24 \\
16 \\
11\end{array}$ & $\begin{array}{l}30.5 \\
31.5 \\
33.0 \\
42.6\end{array}$ & $\begin{array}{l}10.1 \\
10.1 \\
10.4 \\
10.0\end{array}$ & $\begin{array}{l}0.74 \\
1.46 \\
1.47 \\
1.39\end{array}$ & $\begin{array}{l}0.32 \\
0.43 \\
0.46 \\
0.40\end{array}$ & $\begin{array}{l}0.34-1.45 \\
0.63-2.32 \\
0.68-2.17 \\
0.82-2.13\end{array}$ & $\begin{array}{l}1.38 \\
1.36 \\
1.40\end{array}$ & $\begin{array}{l}1.35 \\
1.30 \\
1.40\end{array}$ & $\begin{array}{c}40.8 \\
74.4 \\
75.6 \\
\end{array}$ & $\begin{array}{c}11.2 \\
59.7 \\
50.9 \\
.\end{array}$ \\
\hline \multicolumn{11}{|l|}{ Referents } \\
\hline $\begin{array}{l}\text { Initial } \\
\text { One-year reexamination } \\
\text { Two-year reexamination } \\
\text { Four-year reexamination }\end{array}$ & $\begin{array}{l}33 \\
33 \\
31 \\
10\end{array}$ & $\begin{array}{l}31.0 \\
32.0 \\
31.4 \\
36.0\end{array}$ & $\begin{array}{l}5.6 \\
5.6 \\
5.4 \\
6.2\end{array}$ & $\begin{array}{l}0.51 \\
0.51 \\
0.50 \\
0.33\end{array}$ & $\begin{array}{l}0.18 \\
0.16 \\
0.19 \\
0.12\end{array}$ & $\begin{array}{l}0.05-1.01 \\
0.29-0.87 \\
0.24-1.01 \\
0.19-0.58\end{array}$ & $\begin{array}{l}0.51 \\
0.51 \\
0.40\end{array}$ & $\begin{array}{l}0.14 \\
0.14 \\
0.39\end{array}$ & $\begin{array}{c}41.7 \\
38.9 \\
41.9 \\
.\end{array}$ & $\begin{array}{r}11.8 \\
10.1 \\
9.0\end{array}$ \\
\hline
\end{tabular}

a $1 \mu \mathrm{g} \mathrm{ZnPP}$ is equivalent to $0.018 \mu \mathrm{mol}$. 
vous system, and they have proved to be sensitive to the early effects of lead in previous cross-sectional studies $(6,9,18)$. They have been described in detail in another publication (10).

Cognitive functions were measured with three tests from the Wechsler Adult Intelligence Scale (25): Similarities, a verbal intelligence test (raw score maximum 26); Block Design, a reasoning task which measures visuoconstructive functions (raw score maximum 48); and Picture Completion, a test of perceptual organization (raw score maximum 21).

Three tests of the Wechsler Memory Scale (21) were used to measure concentration and short-term memory. They were Digit Span, a task which involves the immediate recall of digits (raw score maximum 17); Logical Memory, a verbal memory test (raw score maximum 23); and Visual Reproduction, a visual memory test (raw score maximum 14).

Visuomotor functions were studied by the Bourdon-Wiersma Vigilance Test, a clerical inspection task which measures the speed and inaccuracy of visuomotor performance, as well as fluctuations in speed. The number of rows completed in $8 \mathrm{~min}$ indicated the speed of performance. Inaccuracy was measured as the number of errors and omissions. Fluctuation in speed was defined as the difference between the means of the three longest and the three shortest times for row performance.

Another test used was the Santa Ana Dexterity Test, in which the task is to turn pegs successively $180^{\circ}$. It measures both the speed of manual dexterity and visuomotor coordination. It is performed separately with the preferred hand (Santa Ana right) and the nonpreferred hand (Santa Ana left), and hand coordination is checked by simultaneous performance with both hands (Santa Ana coordination). The numerical values refer to the number of pegs turned in two 30-s trials.

The Eysenck Personality Inventory (3) was used to test personality. The results of the personality inventory and the questionnaire on subjective symptoms will be reported elsewhere. Similarities, Picture Completion, and the Eysenck Personality Inventory were used only at the initial examination and at the four-year reexamination because their results are easily affected by memory. To avoid learning effects, parallel versions of the tests from the Wechsler Memory Scale were used to test memory. The Finnish standardization of the Wechsler Adult Intelligence Scale (20) and the data collected at our institute made it possible to compare the results with the mean scores for corresponding groups of other industrial workers.

\section{Data analysis}

As the size of the samples was small, mostly nonparametric methods were used. The two-sided sign test (17) was used to examine changes in the subjects' intraindividual performance, ie, to determine whose performance improved, remained stable, or deteriorated during the follow-up period. Group comparisons between the lead workers and the referents were tested by the chi-square test (5) and a two-sided Kolmogorov-Smirnov test (17). The relations between the changes in performance and the uptake of lead were inspected with the exposed group split into two subgroups by the median of the timeweighted average of their $\mathrm{B}-\mathrm{Pb}$ values. The performances of these subgroups were also compared with the referents' performances. The relation between the degree of lead uptake and the extent to which performance changed was analyzed with a stepwise linear regression analysis (2), the different background factors which affected the tests also being taken into consideration. In this procedure the following factors were selected as independent variables in the regression analysis: the level of exposure (median of the time-weighted average $\mathrm{B}-\mathrm{Pb}$ values), the duration of exposure, age, and the primary level on the psychological tests (the test score at the initial examination).

When the data were analyzed, attention was primarily paid to the results obtained at the two-year reexamination, particularly to the results of the Santa Ana and Block Design tests, as these had proved to be the most sensitive tests in our earlier cross-sectional study (9).

\section{Results}

\section{Comparison between the exposed workers and the referents}

Table 2 presents the initial mean performances of both groups on the various tests.

The mean scores of the lead workers and the referents on the tests of the Wechsler Adult Intelligence Scale agreed with the standard score 10 of the corresponding age group in the Finnish standardization of the Scale. Similarly the mean scores on the other tests corresponded with the mean scores of other groups of industrial workers (10). Initially the mean psychological performances were similar for the lead workers and the referents.

At the one-year reexamination the performance of the reference group showed statistically significant improvement in five of the nine test variables. The most improvement occurred in visuomotor speed, as measured by the Bourdon-Wiersma task ( $\mathrm{p}<0.001$ ). The lead workers had more declined than improved results for four variables (Block Design, Digit Span, Bourdon-Wiersma fluctuation, and Santa Ana coordination). The differences between the lead workers and the referents were statistically significant at the $1 \%$ level for the Block Design test $\left(\chi_{1}^{2}=12.7\right)$ and the Santa Ana coordination test $\left(\chi_{1}^{2}=10.8\right)$. 
Table 2. Mean values and standard deviations of the psychological test variables at the initial examination of lead workers and their referents.

\begin{tabular}{|c|c|c|c|c|}
\hline \multirow[t]{2}{*}{ Test variable } & \multicolumn{2}{|c|}{$\begin{array}{l}\text { Lead workers } \\
\qquad(\mathrm{N}=24)\end{array}$} & \multicolumn{2}{|c|}{$\begin{array}{l}\text { Referents } \\
(N=33)\end{array}$} \\
\hline & Mean & SD & Mean & SD \\
\hline $\begin{array}{l}\text { Similarities } \\
\text { Picture Completion } \\
\text { Block Design }\end{array}$ & $\begin{array}{l}19.1 \\
14.9 \\
33.3\end{array}$ & $\begin{array}{l}2.7 \\
3.6 \\
8.5\end{array}$ & $\begin{array}{l}20.2 \\
14.9 \\
35.3\end{array}$ & $\begin{array}{l}2.6 \\
3.5 \\
8.8\end{array}$ \\
\hline $\begin{array}{l}\text { Digit Spanb } \\
\text { Logical Memory }^{b} \\
\text { Visual Reproduction }\end{array}$ & $\begin{array}{l}10.1 \\
11.0 \\
10.8\end{array}$ & $\begin{array}{l}1.7 \\
3.6 \\
2.7\end{array}$ & $\begin{array}{l}10.8 \\
12.6 \\
10.7\end{array}$ & $\begin{array}{l}1.7 \\
3.4 \\
2.8\end{array}$ \\
\hline $\begin{array}{l}\text { Bourdon-Wiersma speed } \\
\text { Bourdon-Wiersma inaccuracy } \\
\text { Bourdon-Wiersma fluctuation }\end{array}$ & $\begin{array}{l}32.9 \\
21.2 \\
59.8\end{array}$ & $\begin{array}{r}7.3 \\
18.5 \\
25.9\end{array}$ & $\begin{array}{l}31.9 \\
14.6 \\
60.0\end{array}$ & $\begin{array}{r}5.5 \\
10.4 \\
19.4\end{array}$ \\
\hline $\begin{array}{l}\text { Santa Ana right } \\
\text { Santa Ana left } \\
\text { Santa Ana coordination }\end{array}$ & $\begin{array}{l}49.3 \\
43.3 \\
29.7\end{array}$ & $\begin{array}{l}6.7 \\
5.7 \\
5.1\end{array}$ & $\begin{array}{l}47.0 \\
42.3 \\
28.0\end{array}$ & $\begin{array}{l}6.4 \\
7.1 \\
5.8\end{array}$ \\
\hline
\end{tabular}

a From the Wechsler Adult Inteltigence Scale.

b From the Wechsler Memory Scale.

Table 3. Changes in the psychological performance of lead workers and their referents during two years of follow-up. $1-=$ performance deteriorated, $0=$ no change in performance, $+=$ performance improved, NS $=$ not significant)

\begin{tabular}{|c|c|c|c|c|c|c|c|c|c|c|c|}
\hline \multirow[b]{2}{*}{ Test variable } & \multicolumn{5}{|c|}{ Lead workers } & \multicolumn{5}{|c|}{ Referents } & \multirow{2}{*}{$\begin{array}{l}\text { Differences } \\
\text { between the lead } \\
\text { workers and their } \\
\text { referents } \\
\left(\chi_{1}{ }^{2}\right)\end{array}$} \\
\hline & $N$ & - & 0 & + & $\begin{array}{l}\text { Sign test } \\
(p)\end{array}$ & $\mathrm{N}$ & - & 0 & + & $\begin{array}{l}\text { Sign test } \\
\text { (p) }\end{array}$ & \\
\hline Block Design a & 14 & 10 & 1 & 3 & $<0.10$ & 31 & 0 & 9 & 22 & $<0.001$ & $23.7^{* * *}$ \\
\hline Digit Span ${ }^{5}$ & 16 & 10 & 5 & 1 & $<0.05$ & 31 & 9 & 11 & 11 & NS & $6.3^{*}$ \\
\hline Visual Reproduction ${ }^{b}$ & 16 & 5 & 1 & 10 & NS & 31 & 6 & 5 & 20 & $<0.01$ & 0.5 \\
\hline Bourdon-Wiersma speed & 15 & 1 & 3 & 11 & $<0.01$ & 30 & 4 & 2 & 24 & $<0.001$ & 0.3 \\
\hline $\begin{array}{l}\text { Bourdon-Wiersma errors } \\
\text { Bourdon-Wiersma }\end{array}$ & 15 & 6 & 2 & 7 & NS & 30 & 9 & 4 & 17 & NS & 0.5 \\
\hline fluctuation & 15 & 5 & 1 & 9 & NS & 30 & 11 & 3 & 16 & NS & 0.1 \\
\hline Santa Ana right & 16 & 7 & 3 & 6 & NS & 31 & 4 & 12 & 15 & $<0.05$ & 3.7 \\
\hline Santa Ana left & 16 & 8 & 1 & 7 & NS & 31 & 6 & 12 & 13 & NS & 1.6 \\
\hline Santa Ana coordination & 15 & 9 & 4 & 2 & $<0.10$ & 31 & 3 & 11 & 17 & $<0.01$ & $13.4^{* * *}$ \\
\hline
\end{tabular}

a From the Wechsler Adult Intelligence Scale.

b From the Wechsler Memory Scale.

${ }^{*} p<.0 .05,{ }^{* *} p<0.01,{ }^{* *} p<0.001$.

Table 4. Regression analysis of the changes in performances on the Block Design and Santa Ana coordination tests during the two-year follow-up period as a function of different exposure levels. ( $\mathrm{B}-\mathrm{Pb}=$ blood lead)

\begin{tabular}{|c|c|c|c|c|}
\hline Regressor & $\begin{array}{l}\text { Regression } \\
\text { coefficient }\end{array}$ & t-Value & $\mathbf{R}^{2}$ & $\mathrm{~F}$ \\
\hline \multicolumn{5}{|l|}{ Change in Block Design } \\
\hline $\begin{array}{l}\text { Constant } \\
\text { Time-weighted average B-Pb level } \leq 1.30 \mu \mathrm{mol} / / \\
\text { Time-weighted average B-Pb level }>1.30 \mu \mathrm{mol} / \mathrm{I}\end{array}$ & $\begin{array}{r}1.55 \\
-2.88 \\
-2.69\end{array}$ & $\begin{aligned} & 3.35^{* *} \\
&-2.96^{\star *} \\
&-2.50^{*}\end{aligned}$ & 0.22 & $6.3^{\star *}$ \\
\hline \multicolumn{5}{|l|}{ Change in Santa Ana coordination } \\
\hline $\begin{array}{l}\text { Constant } \\
\text { Time-weighted average B-Pb level } \leq 1.30 \mu \mathrm{mol} / / \\
\text { Time-weighted average B-Pb level }>1.30 \mu \mathrm{mol} / /\end{array}$ & $\begin{array}{r}1.16 \\
-3.05 \\
-0.73\end{array}$ & $\begin{aligned} & 2.16^{\star} \\
- & 2.70^{\star \star} \\
- & 0.58\end{aligned}$ & $\dot{0.14}$ & $3.7^{*}$ \\
\hline
\end{tabular}

${ }^{*} p<0.05, * * p<0.01$

At the two-year reexamination the lead workers had a continued and even more pronounced deterioration in performances, whereas the referents still had improved performances on most of the tests (table 3). The Block Design and the Santa Ana coordination tests now yielded a group difference at the significance level of $0.1 \%$, and an additional statistically significant difference was detected for the Digit Span test.

Figures 1 and 2 show both the degree of positive and negative changes in performance on the Block Design and the Santa Ana coordination tests and also 
the statistical significances of the group differences when the cumulative distributions of the changed scores were compared. The changes in Block Design recorded among the lead workers ranged from decrement in nine raw scores to improvement in eight; those recorded among the referents varied from no change to improvement in eight scores. The range of changes in the score of the Santa Ana coordination was wide in both groups, but there were only a few decreased scores among the referents.

At the four-year reexamination the performances of both groups were markedly reduced. There were statistically significant differences at the $5 \%$ level for Santa Ana coordination $\left(\chi_{1}^{2}=7.2\right)$ and Bourdon-Wiersma fluctuation $\left(\chi_{1}^{2}=6.5\right)$, but the low number of subjects renders significance testing less meaningful.

Examination of the results obtained throughout the follow-up period revealed that the most sensitive indicators of psychological impairments among lead workers in this study were the Block Design test, the Santa Ana coordination test, and, at a lower level of probability, the Digit Span test. However, despite decrements in performance, all test scores were within the normal range of variation.

\section{Comparison within the exposed group}

There were no initial differences in performance between the workers in the "high" and "low" lead groups. The regression analysis plotted the scores of the changes in performance against the time-weighted average $\mathrm{B}-\mathrm{Pb}$ values. It revealed that no statistically significant changes had occurred in the "low lead" group during the first year, whereas some slight deterioration in visuomotor performance could be detected in the "high lead" group.

Two years of exposure had produced more changes in psychological performances. The multiple correlation coefficient of the regression model was 0.47 , and the F-value was $12.8(\mathrm{p}<0.01)$. Table 4 shows the results of the regression analysis after two years of follow-up for the Block Design and the Santa Ana coordination tests. On the Block Design test significant differences were found for the changes in the scores of both subgroups exposed to lead when compared with the changes in the referents' scores. The scores of the "high lead" group on the Santa Ana coordination test failed to predict changes in performance because of the wide dispersion (as can be seen in figure 4).

Figures 3 and 4 illustrate the relationship between the time-weighted average $\mathrm{B}-\mathrm{Pb}$ values and the changes in performance. The changes in psychological performances were wide for the lead workers whose values were between 0.68 and $2.17 \mu \mathrm{mol} / \mathrm{l}$. Except for at the initial examination, the referents performed the tests more uniformly than the leadexposed workers.
To obtain more clarification of the changes in performance, the regression analysis was repeated with exposure, age, and the primary level of psychological performance as background variables (table 5). In addition to exposure, the primary level was a statistically significant regressor to the regressants, ie, workers whose general performance level was higher in the initial examination had fewer performance decrements and/or more improvements than workers with lower scores at the beginning of the follow-up. Age did not offer any auxiliary explanation for the changes in performance.

At the four-year reexamination the number of lead workers had dropped because of turnover, especially in the "high lead" group; the mean time-weighted

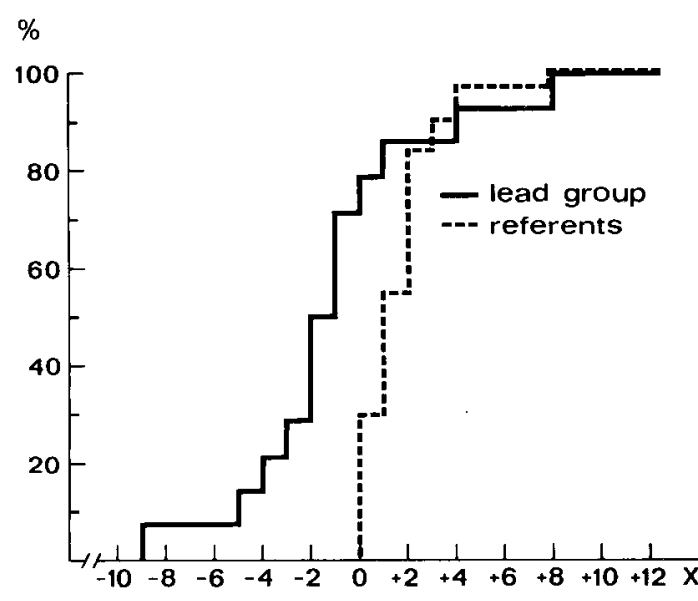

Two-sided Kolmogorov-Smirnov test: greatest distance at $X=-1, D=71.4, p<0.01$

Figure 1. Change in the results of the Block Design test during two years of follow-up.

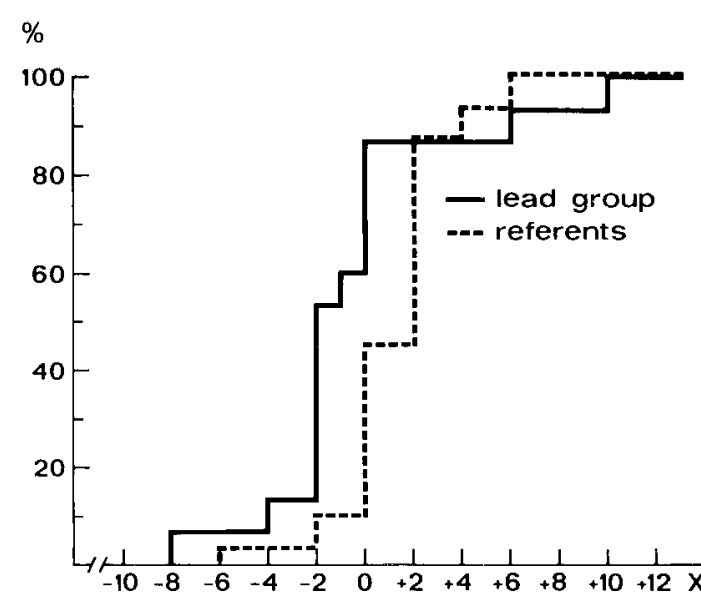

Two-sided Kolmogorov-Smirnov test; greatest distance at $X=-1, D=50.3, p<0.05$

Figure 2. Change in the results of the Santa Ana coordination test during two years of follow-up. 


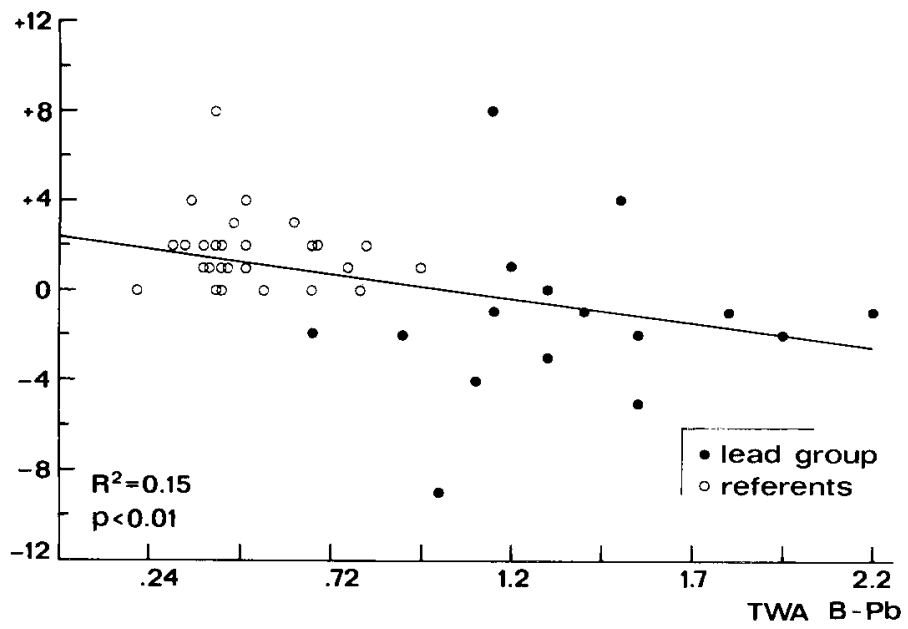

Figure 3. Changes in the performances on the Block Design (BD) test during the two-year follow-up period as a function of the time-weighted average blood lead (TWA B-Pb) levels.

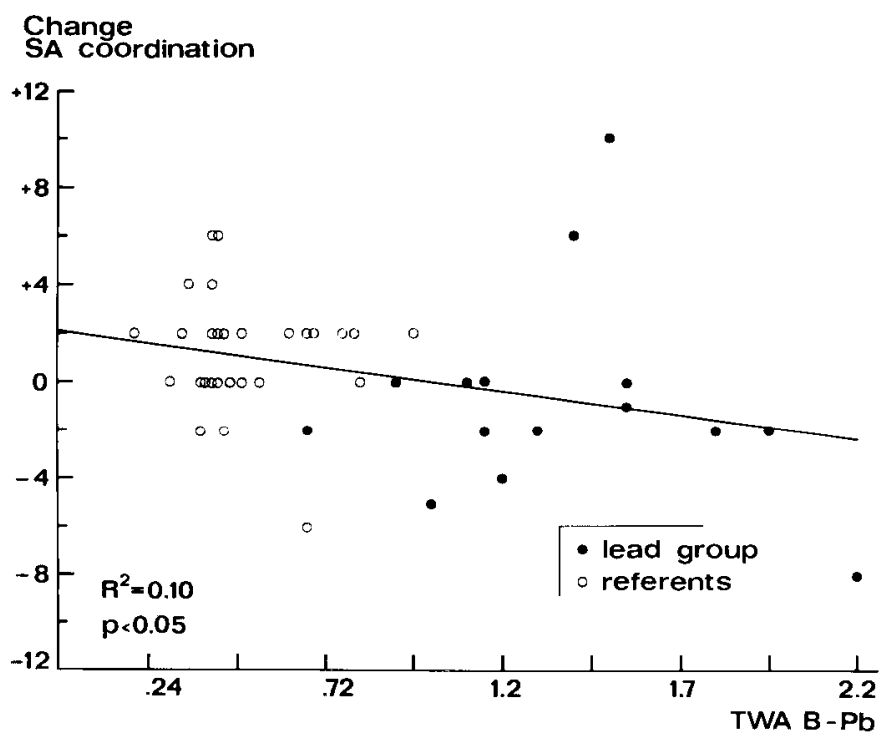

Figure 4. Changes in the performances on the Santa Ana (SA) coordina. tion test during the two-year follow-up period as a function of the timeweighted blood lead (TWA B-Pb) levels.

average of the $\mathrm{B}-\mathrm{Pb}$ values of the dropouts was 1.64 $\mu \mathrm{mol} / \mathrm{l}$. As a consequence the differences between the subgroups were reduced, and all were statistically insignificant.

\section{Discussion}

The decrements recorded for the performances of the lead workers during the follow-up period indicate that lead affects the efficiency of some functions of the central nervous system at very low exposure levels and already during the first years of the work history. However, the psychological impairments found were slight and did not affect all performances.

It is notable that the deterioration recorded for performance was a net effect resulting from lead toxicity on one hand and the opposite effects of learning and training on the other. The effects of learning and training were clear among most of the referents, who improved their performances in the successive reexaminations. The performances of the lead workers, by contrast, continued to deteriorate more often than they improved.

The performances most affected by lead depended on visual intelligence and visuomotor functions. This result is coherent with the results of other studies on lead-exposed workers $(4,6,8,9,12,18,19)$. Of the performance tests used in this prospective study, the Block Design test and the Santa Ana coordination test appeared to be the most sensitive indicators of lead-induced impairment. The results have been similar with respect to other toxic substances (7) and also in earlier cross-sectional studies on lead $(6,9,18)$. Both tests require complex psychological functions, ie, the cognitive processing of visual material and visuomotor integration, not only motor speed. 
Table 5. Regression analysis of the changes in performances on the Block Design and Santa Ana coordination tests as a function of various background variables.

\begin{tabular}{|c|c|c|c|c|}
\hline Regressor & $\begin{array}{l}\text { Regression } \\
\text { coefficient }\end{array}$ & t-Value & $\mathrm{R}^{2}$ & $\mathrm{~F}$ \\
\hline \multicolumn{5}{|c|}{ Change in Block Design } \\
\hline $\begin{array}{l}\text { Constant } \\
\text { Exposure }\end{array}$ & $\begin{array}{r}1.55 \\
-2.88\end{array}$ & $\begin{array}{c}3.39^{\star *} \\
-3.57^{\star \star *}\end{array}$ & 0.22 & $12.8^{* * *}$ \\
\hline $\begin{array}{l}\text { Constant } \\
\text { Exposure } \\
\text { Age }\end{array}$ & $\begin{array}{r}2.84 \\
-2.73 \\
-0.04\end{array}$ & $\begin{array}{l}1.71 \\
-3.45^{\star * *} \\
-0.80\end{array}$ & 0.23 & $6.68^{* *}$ \\
\hline $\begin{array}{l}\text { Constant } \\
\text { Exposure } \\
\text { Primary level }\end{array}$ & $\begin{array}{r}4.31 \\
-2.79 \\
-0.08\end{array}$ & $\begin{aligned} & 2.76^{\star \star} \\
- & 3.65^{\star \star \star} \\
- & 1.84\end{aligned}$ & 0.28 & $8.45^{\text {* }}$ \\
\hline \multicolumn{5}{|c|}{ Change in Santa Ana coordination } \\
\hline $\begin{array}{l}\text { Constant } \\
\text { Exposure }\end{array}$ & $\begin{array}{r}1.16 \\
-2.04\end{array}$ & $\begin{array}{r}2.13^{\star} \\
-2.18^{*}\end{array}$ & 0.10 & $4.78^{\star}$ \\
\hline $\begin{array}{l}\text { Constant } \\
\text { Exposure } \\
\text { Age }\end{array}$ & $\begin{array}{r}1.81 \\
-2.00 \\
-0.02\end{array}$ & $\begin{array}{l}0.91 \\
-2.11^{\star} \\
-0.33\end{array}$ & 0.10 & 2.40 \\
\hline $\begin{array}{l}\text { Constant } \\
\text { Exposure } \\
\text { Primary level }\end{array}$ & $\begin{array}{r}6.00 \\
-1.77 \\
-0.17\end{array}$ & $\begin{aligned} & 2.80^{* *} \\
- & 1.97^{*} \\
- & 2.32^{*}\end{aligned}$ & 0.20 & $5.33^{\star *}$ \\
\hline
\end{tabular}

* $p<0.05,{ }^{* *} p<0.01,{ }^{* \star *} p<0.001$.

It is possible that routinely performed tasks do not show impairment, whereas tasks that demand new learning or complex psychological functions may be more sensitive to subclinical effects. Among the exposed workers, the "high lead" group tended to have the most decrements in the Block Design and Santa Ana tests. However, the changes in psychological performances found among the lead workers varied widely, and the results do not support the existence of a strong linear relation between performances and the $\mathrm{B}-\mathrm{Pb}$ values when the time-weighted average varies between 0.68 and $2.17 \mu \mathrm{mol} / \mathrm{l}$.

The regression analysis indicated that the early effects of exposure can easily be concealed by interindividual differences if the variation in the level of exposure is slight. Intervening variables (such as variation in the ability and motivation to compensate for functional impairments with increased effort) can also mask the toxic effects on performance.

This study, which unfortunately became hampered by a high frequency of dropout, could not define any exact threshold between a noneffect level and a risk level, except for the observation that more changes occurred in the workers whose time-weighted average $\mathrm{B}-\mathrm{Pb}$ value was over $1.30 \mu \mathrm{mol} / \mathrm{l}$ when compared with those whose corresponding value remained below this level. The slight psychological impairment found in the higher $\mathrm{B}-\mathrm{Pb}$ group has probably no practical importance with regard to mental health or work ability. Rather the importance of these impairments lies in their nature as warning signals that indicate incipient changes in the function of the central nervous system. However, in subjects with restricted adaptive resources, the effects of exposure to a moderate level of lead can essentially lower the ability to cope with the demands of everyday life.
In conclusion the present study showed that, although the impairment of performance among lead workers was slight, some higher nervous functions were affected by rather low levels of exposure. Slight damage to the peripheral nervous system, evident as reductions in some nerve conduction velocities, also occurred in the same workers $(15,16)$. Hence $\mathrm{B}-\mathrm{Pb}$ levels in excess of about $1.45 \mu \mathrm{mol} / 1$ had detectable effects on both central and peripheral nervous functions. This multiple action increases the importance of any isolated finding as an early warning signal for more severe and more widespread consequences.

\section{Acknowledgments}

The authors express their gratitude to Dr B Kock, Akkuteollisuus Oy, Espoo, for his help and cooperation. We also wish to thank Ms R Vesanto, T Martelin, MA, and L Tenkanen, MA, from the Institute of Occupational Health, Helsinki, for their technical and statistical help.

\section{References}

1. Blumberg WE, Eisinger J, Lamola AA, Zuckerman DM. Zinc protoporphyrin level in blood determined by a portable hematofluorometer: A screening device for lead poisoning. J lab clin med 89 (1977) 712-723.

2. Draper NR, Smith H. Applied regression analysis. Second edition, John Wiley \& Sons, New York, NY 1981.

3. Eysenck H, Eysenck S. Manual of the Eysenck personality inventory. University of London Press, London 1964.

4. Feldman RG, Ricks NL, Baker EL. Neuropsychological effects of industrial toxins: A review. Am j ind med 1 (1980) $211-227$. 
5. Glanz SA. Primer of biostatistics. McGraw-Hill, New York, NY 1981.

6. Grandjean P, Arnvig E, Beckmann J. Psychological dysfunctions in lead-exposed workers. Scand $\mathrm{j}$ work environ health 4 (1978) 295-303.

7. Hänninen H. Psychological test methods: Sensitivity to long term chemical exposure at work. Neurobehav toxicol 1 (1979) $157-161$.

8. Hänninen H. Behavioral effects of occupational exposure to mercury and lead. In: Juntunen J, ed. Occupational neurology. Acta neurol scand suppl 92 (1982): $66,167-175$.

9. Hänninen H, Hernberg S, Mantere P, Vesanto R, Jalkanen M. Psychological performance of subjects with low exposure to lead. J occup med 20 (1978) 683-689.

10. Hänninen $\mathbf{H}$, Lindström $\mathrm{K}$. Behavioral test battery for toxicopsychological studies: Used at the Institute of Occupational Health in Helsinki. Second edition. Institute of Occupational Health, Helsinki 1979.

11. Hessel A. A simple and rapid quantitative determination of lead in blood. At absorpt newsl 7 (1968) $55-56$.

12. Hogstedt C, Hane M, Agrell A, Bodin L. Neuropsychological test results and symptoms among workers with well-defined long-term exposure to lead. $\mathrm{Br} \mathrm{j}$ ind med 40 (1983) 99-105.

13. Mantere $P$, Hänninen $H$, Hernberg S. Subclinical neurotoxic lead effects: Two-year follow-up studies with psychological test methods. Neurobehav toxicol teratol 4 (1982) $725-727$

14. Needleman HL. The neurobehavioral consequences of low lead exposure in childhood. Neurobehav toxicol teratol 4 (1982) 729-732.

15. Seppäläinen AM, Hernberg S, Kock B. Relationship between blood lead levels and nerve conducting velocities. Neurotoxicology 1 (1979) 313-332.

16. Seppäläinen $A M$, Hernberg $S$, Vesanto $R$, Kock B. Early neurotoxic effects of occupational lead exposure
- A prospective study. Neurotoxicology 181-192.

17 Siegel S. Nonparametric statistics for the behavioral sciences. McGraw-Hill, Kogakusha Ltd, Tokyo 1956.

18. Valciukas J, Lilis R, Eisinger J, Blumberg W, Fischbein $A$, Selikoff I. Behavioral indicators of lead neurotoxicity: Results of a clinical field survey. Int arch occup environ health 41 (1978) 217-236.

19. Valciukas J, Lilis R, Singer R, Fischbein A, Anderson HA, Glickman L. Lead exposure and behavioral changes: Comparisons of four occupational groups with different levels of lead absorption. Am $\mathbf{j}$ ind med 1 (1980) 421-426.

20. Wechsler D. Wechslerin aikuisten älykkyysasteikko. Vakaaminen Suomessa ja käsikirjan laadinta (K v Fieandt ja E Kalimo). Psykologien Kustannus Oy, Helsinki 1975 .

21. Wechsler D. A standardized memory scale for clinical use. J psychol 19 (1945) 87-95.

22. Winneke G, Krämer U, Brockhaus A, Ewers U, Kujanek $G$, Lechner $H$, Janke $W$. Neuropsychological studies in children with elevated tooth-lead concentrations. Int arch occup environ health 51 (1983) $231-252$.

23. World Health Organization. Recommended healthbased limits in occupational exposure to heavy metals. World Health Organization, Geneva 1980. (WHO technical report review 647).

24. World Health Organization. Environmental health criteria: 3. Lead. World Health Organization, Geneva 1977.

25. Zimmerman IL, Woo-Sam JM. Clinical interpretation of the Wechsler adult intelligence scale. Grune \& Stratton, New York, NY 1973.

Received for publication: 1 November 1983 